\title{
Conservation of the red-shanked douc Pygathrix nemaeus in Lao People's Democratic Republic: density estimates based on distance sampling and habitat suitability modelling
}

\author{
C. N. Z. Coudrat, C. Nanthavong and K. A. I. Nekaris
}

\begin{abstract}
The Endangered red-shanked douc Pygathrix nemaeus is a charismatic Asian colobine endemic to Vietnam, Cambodia and Lao People's Democratic Republic (PDR). The largest population is found in central-eastern Lao PDR but it has never been quantified. We conducted line-transect surveys in Nakai-Nam Theun National Protected Area in 2011-2012. We used distance sampling combined with a habitat suitability model to estimate group density and group abundance in the area. Our analysis yielded a density of 2.8 (range 1.9-4.1) groups per $\mathrm{km}^{2}$ and c. 4,420 groups within the predicted c. 1,600 $\mathrm{km}^{2}$ of suitable habitat in Nakai-Nam Theun. These are the only available data for P. nemaeus in Lao PDR to date. We discuss the limitations of our survey, which involved potential violations of the distance sampling method, and highlight the challenges of using this method for primates. We also consider the importance of assessing limitations in distance sampling studies, to evaluate reliability and facilitate comparisons. The population of $P$. nemaeus in Lao PDR is under threat from illegal hunting and is not the focus of any specific conservation action. To avoid a repetition of the decline the species has already experienced in Vietnam, and to secure the species' global survival, conservation projects need to target the population in Nakai-Nam Theun. A long-term conservation and research project in this key biodiversity area will also benefit other threatened and unique co-existing species.
\end{abstract}

Keywords Distance sampling, habitat suitability monitoring, Lao PDR, line transect, Nakai-Nam Theun National Protected Area, Pygathrix nemaeus, red-shanked douc, species distribution modelling

C. N. Z. Coudrat (Corresponding author) and K. A. I. NeKaris Anthropology Centre for Conservation, Environment and Development, Department of Anthropology and Geography, School of Social Science and Law, Oxford Brookes University, OX3 0BP, Oxford, UK. E-mail camillecoudrat@gmail.com

C. NAnthavong Nam Theun 2 Watershed Management and Protection Authority, Ban Oudomsouk, Nakai District, Lao People's Democratic Republic

Received 17 October 2012. Revision requested 7 December 2012.

Accepted 9 January 2013. First published online 26 November 2013.

\section{Introduction}

Tn the tropics South-east Asia has the largest proportion 1 of endemic mammals and is also the region where mammals face the greatest threat of extinction (Sodhi et al., 2009). The scientific community has reached a consensus that the region is facing a biodiversity crisis and therefore requires strategic conservation planning and implementation of conservation actions (Sodhi et al., 2004; Koh \& Sodhi, 2010; Duckworth et al., 2012). Estimating animal population abundance using surveys can have several implications for addressing biodiversity crises (Ogutu et al., 2006; Hassel-Finnegan et al., 2008). Identifying important populations is a key step in setting conservation priorities and is necessary for monitoring population status over time (Plumptre \& Cox, 2006). The lack of resources devoted to the conservation of lesser known yet highly threatened species means that the conservation status assigned to many taxa is based on single short-term surveys or has not been verified.

The red-shanked douc Pygathrix nemaeus, categorized as Endangered on the IUCN Red List (IUCN, 2012), is an Asian colobine monkey that belongs to a monophyletic group, along with two other douc species (Pygathrix nigipes and Pygathrix cinerea). All three are endemic to Lao People's Democratic Republic (PDR), Cambodia and Vietnam (occurring in one, two or all three of these countries, depending on the species). P. nemaeus occurs in Vietnam and Lao PDR and perhaps Cambodia (Rawson \& Roos, 2008; Coudrat et al., 2012). With the remaining populations in Vietnam estimated at no more than 30 individuals (Bach Ma National Park; Nadler, 2010) to c. 2,00o individuals (Phong Nha-Ke Bang National Park; Haus et al., 2009), and with constant hunting pressure on douc species for traditional medicine, local consumption and international trade, the security of the species in Vietnam is uncertain. The largest population of $P$. nemaeus is known to occur in Lao PDR, in particular in the central-eastern part of the country, in the foothills of the Annamite mountain range and some adjacent lowland areas (Timmins \& Duckworth, 1999; Coudrat et al., 2012). However, there is no population estimate for the species, which is increasingly threatened by hunting pressure in these remote, relatively large and dense forests (Coudrat et al., 2012). Baseline density estimates for $P$. nemaeus in the region will facilitate long-term monitoring and assessment of conservation success. 


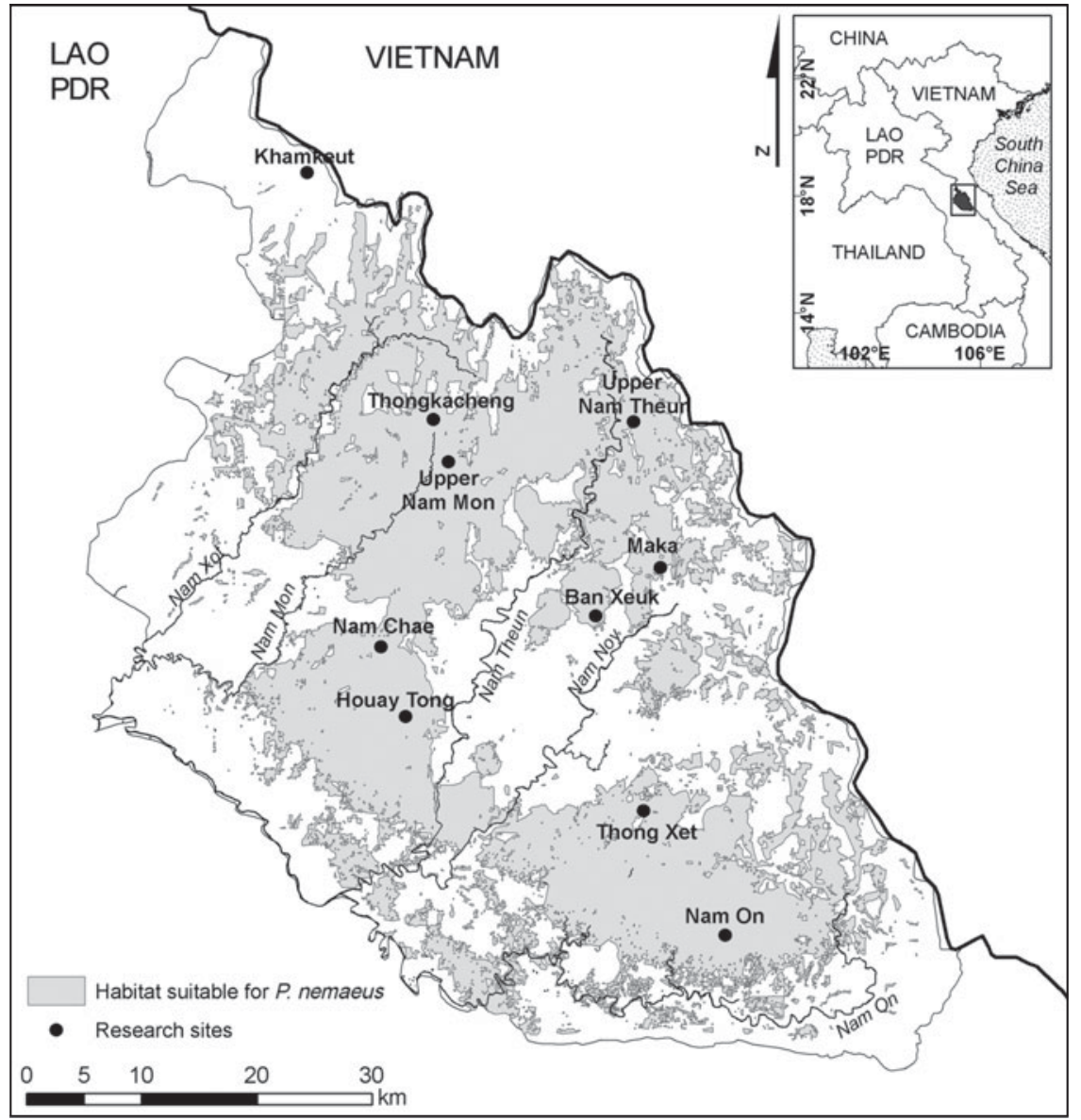

FIG. 1 Nakai-Nam Theun National Protected Area, where we carried out transect surveys at 10 sites during 2011-2012. Habitat suitability for the red-shanked douc Pygathrix nemaeus was modelled using MAXENT. Continuous logistic suitability was reclassified to obtain the binary map, under the minimum training presence threshold, resulting in a suitable habitat of $1,578 \mathrm{~km}^{2}$. The rectangle on the inset shows the location of the main map in LAO PDR.
To provide baseline data for the conservation of this species we conducted line-transect surveys over one year during 2011-2012 in Nakai-Nam Theun National Protected Area. We combined species distribution modelling and distance sampling (Buckland et al., 2001) to estimate the density and population abundance of $P$. nemaeus, and based on our results we suggest a conservation action plan for the world's largest remaining population of red-shanked douc.

\section{Study area}

Nakai-Nam Theun National Protected Area (c. $3,500 \mathrm{~km}^{2}$ ) is located in central-eastern Lao PDR, in the Annamite mountain range (Fig. 1). The Protected Area remains largely forested, with c. $80 \%$ forest cover (Robichaud et al., 2009) and a variety of habitat types, including mixed semievergreen/coniferous, upper montane, dry evergreen and wet evergreen forests (Timmins \& Evans, 1996). Elevation in the Protected Area is 500-2,300 m. Annual precipitation is $1,865-2,620 \mathrm{~mm}$ and annual mean temperature is $14-24^{\circ} \mathrm{C}$, with extremes of $4-32{ }^{\circ} \mathrm{C}$. Five main rivers cross Nakai-Nam Theun. There are land delimitation zones around the 31 enclave villages for local use of forest products, under the
Wildlife and Aquatic Law and Forestry Law (National Assembly Lao PDR, 2007a,b).

The heterogeneity of habitats makes the wildlife community in Nakai-Nam Theun one of the most diverse in the region, with numerous globally threatened species, including recently discovered large mammals, $>430$ species of birds, nine species of primates and key carnivore species (Timmins \& Evans, 1996). This makes the area a priority for wildlife conservation in Lao PDR and the Indo-Burma region (Robichaud et al., 2001; Tordoff et al., 2012).

\section{Methods}

\section{Data collection}

In 2011-2012 we visited 10 sites across the Protected Area (Fig. 1). We chose these study sites on the basis of their relative accessibility (2-4-days to reach camp). We pre-set transects arbitrarily, without seeking more accessible terrain, on a 1:50,000 topographic map, with a total of 81 transects across the Protected Area. For logistical reasons we set transects approximately perpendicular to a watercourse, and transects were 1-2 km long, 400-500 $\mathrm{m}$ apart and parallel to each other. We kept the pre-set bearing for 
TABle 1 Study sites visited in Nakai-Nam Theun National Protected Area (Fig. 1) during 2011-2012, with the area covered, the total number of transects, the total survey effort, and the number of observations at each site.

\begin{tabular}{|c|c|c|c|c|c|}
\hline Study sites & Dates & Area $\left(\mathrm{km}^{2}\right)^{1}$ & $\begin{array}{l}\text { Transects } \\
\text { (replications) }\end{array}$ & $\begin{array}{l}\text { Total survey } \\
\text { effort }(\mathrm{km})^{2}\end{array}$ & $\begin{array}{l}\text { No. of } \\
\text { observations }^{3}\end{array}$ \\
\hline Nam Chae & 29 Jan.-2 Feb. 2011 & 19.82 & $20(\mathrm{x} 1)$ & 21.47 & 3 \\
\hline Ban Xeuk & 17 Feb.-6 Mar. 2011 & 4.21 & $6(x 3) 1(x 1)$ & 36.16 & 2 \\
\hline Maka & 13-31 Mar. 2011 & 6.05 & $7(\mathrm{x} 3) 1(\mathrm{x} 2)$ & 40.29 & 2 \\
\hline Thong Xet & 18 July-3 Aug. 2011 & 4.97 & $6(\mathrm{x} 1)$ & 10.55 & 3 \\
\hline Khamkeut & 16-28 Sep. 2011 & 4.69 & $6(\mathrm{x} 1)$ & 9.80 & 0 \\
\hline Nam On & 19 Oct. -4 Nov. 2011 & 6.57 & $8(\mathrm{x} 3)$ & 42.45 & 13 \\
\hline Upper Nam Theun & 11-23 Jan. 2012 & 1.96 & $4(\mathrm{x} 3)$ & 22.08 & 3 \\
\hline Houay Tong & 10-27 Feb. 2012 & 9.71 & $10(\mathrm{x} 3)$ & 58.02 & 14 \\
\hline Thongkacheng & 12-24 Mar. 2012 & 4.54 & $6(\mathrm{x} 3)$ & 34.38 & 9 \\
\hline Upper Nam Mon & 25 Mar.-5 Apr. 2012 & 4.99 & $6(\mathrm{x} 3)$ & 35.01 & 13 \\
\hline
\end{tabular}

${ }^{1}$ The size of the study site was estimated using the maximum convex polygon around the transects

${ }^{2}$ Total survey effort includes replications

${ }^{3}$ Seven observations that may have been of a group previously counted on the same transect walk were discarded from the analysis $(n=55 ; \mathrm{N}=62)$

each transect, using a compass, except when we had to go around obstacles (e.g. rivers with no crossing point, large fallen tree trunks). At each study site we walked 4-20 transects, some of which were replicated two or three times, resulting in a total of 176 transects and $310 \mathrm{~km}$ walked (Table 1). The variation in the number of transects and replications between sites was a result of adjustment of the methodology following the first field trip, time constraints and poor weather conditions. We followed distance sampling line-transect methodology (Buckland et al., 2001, 2010): for each group sighting of $P$. nemaeus we recorded the perpendicular distance from animal to transect, using a laser range-finder (sometimes calculated from sin[animal-transect angle $]^{*}$ animal-to-observer distance). We also recorded the coordinates with a geographical positioning system (GPS), time and, whenever possible, an estimate of group size. Dense canopy, movement of the animals (often involving group splitting) and group spread prevented an exact assessment of the centre of a group (Marshall et al., 2008) and therefore we always attempted to record distance to an animal at the centre of all other visible individuals. We moved slowly along transects, given the rugged terrain (walks were of $1.5-5.5$ hours duration). We occasionally stopped to rest but attempted to limit time spent at each resting location. A group of 2-4 people walked each transect.

\section{Species distribution modelling}

We used the maximum entropy general-purpose machine learning method, which has been adapted for species distribution modelling (MAXENT v. 3.3.3k; Phillips et al., 2004, 2006). The method combines biological data of species occurrence (presence-only data, e.g. GPS coordinates) with environmental characteristics to estimate a probability distribution of maximum entropy (i.e. closest to uniform), subject to the set of constraints provided (i.e. environmental characteristics where the species occurs; Phillips et al., 2006). We used a ten-fold cross-validation replication (Kohavi, 1995), using MAXENT's default parameters (Phillips \& Dudik, 2008).

We included 25 variables in the model: 19 bioclimatic layers (Hijmans et al., 2005), elevation, land cover (from 2002, with 14 categories), percentage of forest cover, slope, and distance from water and from villages. To avoid model over-fitting (Veloz, 2009; Merckx et al., 2011; Dormann et al., 2012), occurrence data were corrected for spatial autocorrelation by selecting one locality per $2 \mathrm{~km}^{2}$, resulting in 36 occurrence points for the model $(n=82$, including opportunistic sightings beyond transects). Outputs were analysed using ArcGIS v. 9.3 (ESRI, Redlands, USA). We assessed the model's predictive power using the area under the curve of the receiver-operating characteristic and the Boyce Index (Boyce et al., 2002; Hirzel et al., 2006). To estimate the distribution range of $P$. nemaeus in Nakai-Nam Theun Protected Area we created a binary map, using the minimum training presence threshold.

\section{Distance sampling}

We used DISTANCE 6.0 (Thomas et al., 2010) to analyse survey data, using the conventional distance-sampling engine. We pooled all data collected during the study (Table 1). We removed from the analysis the observations that may have been double counts of the same group on the same transect (of a total of 62 observations). As we could not count group sizes because of poor visibility and fleeing behaviour, we modelled group density rather than individual density and estimated population density post hoc based on the mean group size calculated. Transects that were replicated were analysed together as single lines and their 
TABLE 2 Distance analysis results for different models, calculated with 55 observations and data grouping with five intervals (cut-off points: $0,20,40,60,80,104 \mathrm{~m}$ ), with density estimate, coefficient of variation, probability of detection, $\Delta \mathrm{AIC}$, AIC, and $\chi^{2}$ goodness-of-fit P value.

\begin{tabular}{|c|c|c|c|c|c|c|c|c|}
\hline \multirow{2}{*}{$\begin{array}{l}\text { Model (key function } \\
+ \text { adjustment term) } \\
\text { Half-normal + cosine }\end{array}$} & \multicolumn{2}{|c|}{$\begin{array}{l}\text { Density estimate } \\
\text { (confidence limit) }\end{array}$} & \multirow{2}{*}{$\begin{array}{l}\begin{array}{l}\text { Coefficient } \\
\text { of variation }\end{array} \\
0.19\end{array}$} & \multicolumn{2}{|c|}{$\begin{array}{l}\text { Probability of } \\
\text { detection } \\
\text { (confidence limit) }\end{array}$} & \multirow{2}{*}{$\frac{\Delta \mathrm{AIC}^{*}}{0.00}$} & \multirow{2}{*}{$\frac{\mathrm{AIC}}{131.74}$} & \multirow{2}{*}{$\begin{array}{l}\chi^{2} \text { goodness-of- } \\
\text { fit } \mathrm{P} \text { value } \\
0.38\end{array}$} \\
\hline & 2.81 & $(1.94-4.08)$ & & 0.30 & $(0.24-0.38)$ & & & \\
\hline Half-normal + polynomial & 2.72 & $(1.85-4.01)$ & 0.20 & 0.31 & $(0.24-0.40)$ & 2.57 & 134.30 & 0.11 \\
\hline Uniform + cosine & 2.66 & $(1.81-3.91)$ & 0.20 & 0.32 & $(0.25-0.41)$ & 2.57 & 134.31 & 0.12 \\
\hline Uniform + polynomial & 2.28 & $(1.56-3.33)$ & 0.19 & 0.37 & $(0.29-0.47)$ & 6.17 & 137.91 & 0.02 \\
\hline Half-normal + Hermite & 2.07 & $(1.44-2.98)$ & 0.18 & 0.41 & $(0.33-0.50)$ & 8.12 & 139.86 & 0.01 \\
\hline Uniform + Hermite & 1.63 & $(1.12-2.36)$ & 0.19 & 0.52 & $(0.42-0.65)$ & 15.93 & 147.67 & 0.00 \\
\hline
\end{tabular}

${ }^{\star}$ Delta AIC $=$ model AIC-lowest AIC of all models

survey effort corresponded to the transect length multiplied by the number of replications (Buckland et al., 2010; Table 1).

We followed the line transect analysis steps of Buckland et al. (2001: 135). We plotted our data (perpendicular distances) in a frequency histogram of $10 \mathrm{~m}$ intervals to select five interval cut-off points (o, 20, 40, 60, 80 and $104 \mathrm{~m}$, corresponding to the largest value recorded) and created a grouped data set. We then ran six models with different combinations of key function and adjustment terms: (1) half-normal + cosine, (2) half-normal + simple polynomial, (3) half-normal + Hermite polynomial, (4) uniform + cosine, (5) uniform + simple polynomial, and (6) uniform + Hermite. We selected the best model according to the Akaike information criterion (AIC), the $\chi^{2}$ goodness-of-fit statistical test, and the coefficient of variation of the density estimates (Buckland et al., 2001).

\section{Results}

Our predicted model yielded an area under the curve of 0.789 . The Boyce Index validation method, with 100 classes, indicated a significant $(\mathrm{P}<0.01)$ predictive power $(\mathrm{r}=0.511)$. The resulting predicted distribution range (under the minimum presence training threshold) was $1,578 \mathrm{~km}^{2}, 44 \cdot 4 \%$ of the total area (Fig. 1).

The model with the half-normal key function and cosine adjustment fitted our data the best and resulted in a mean density of 2.8 groups per $\mathrm{km}^{2}$ (Table 2 ). Using this group density and the predicted area of suitable habitat we estimated there are c. 4,420 groups in Nakai-Nam Theun National Protected Area (Table 3).

\section{Discussion}

\section{Survey limitations}

Our analysis yielded a density of 2.8 groups of $P$. nemaeus per $\mathrm{km}^{2}$ and 4,418 groups in Nakai-Nam Theun National
TABLE 3 Abundance estimates calculated by the MAXENT model for various parameters, based on estimated density and range size in Nakai-Nam Theun National Protected Area.

\begin{tabular}{ll}
\hline Parameter & Estimate \\
\hline Mean group encounter rate (range) & $0.2 \mathrm{~km}^{-1}(0-1.7)$ \\
Group density (range) & $2.8 \mathrm{~km}^{-2}(1.9-4.1)$ \\
Mean group size (range) & $13(4-30)$ \\
Individual density & $36.4 \mathrm{~km}^{-2}$ \\
Area of potential range $^{2}$ & $1,578 \mathrm{~km}^{-2}$ \\
\hline
\end{tabular}

${ }^{1}$ Mean of the encounter rates for each transect walk; $\sum_{\mathrm{i}}^{\mathrm{n}={ }^{176}}$ [number of sightings/transect walk $\mathrm{k}_{\mathrm{i}}$ length]/total number of walks $\mathrm{n}$, calculated for the total number of observations (62)

${ }^{2}$ Under the minimum presence training threshold

Protected Area, with our distribution model of an estimated c. $1,600 \mathrm{~km}^{2}$ of suitable habitat. Our habitat suitability model may be underestimated as a result of survey bias (Phillips et al., 2009), mainly in the central regions; it should therefore be considered as a conservative estimate. Given their suspected multi-level social organization, involving regular travel of more than one group together, group size can vary widely (four to c. 30 in our study, excluding solitary animals; Hoang, 2007; Rawson, 2009). Distance sampling has been used for several species of primates but it is difficult to assess reliability because it is rarely possible to assess true density. Using this method for primates can also be challenging because of their behaviour and the difficulty of obtaining sufficiently large and random sample sizes in rainforest habitats, often leading to violation of the technique's assumptions (Buckland et al., 2010). Our results may therefore not represent the true density of the species in the area. However, our study included a large number of transects and replications across the area, resulting in sufficient observations for the models.

Other assumptions could also have been violated: (1) Poor visibility as a result of forest density meant that we were sometimes unable to ascertain the distance to the group centre. By instead estimating the distance to the first animal seen we may have overestimated the density 
(Marshall et al., 2008; Buckland et al., 2010). (2) Some groups may have remained undetected because of disturbance from transect-cutting on the first walk, occasional noisy movement through denser habitat (e.g. bamboo) or poor weather conditions in some areas (e.g. the Khamkeut site). Our detection probability was low (30\%). However, a commonly observed behavioural response of doucs to threat involves at least some individuals remaining hidden in trees, which may have influenced the probability of detection. (3) Most groups were detected while fleeing, which may have affected the density estimate (Marshall et al., 2008) but did not prevent us from identifying species. We were able to identify all 126 primate groups detected (including groups and solitary animals; 12 gibbons, 52 macaques, 62 doucs) at least to genus, doucs being the easiest to identify by their striking colour, locomotion and calls. (4) Some groups may have been counted twice along the same transect. We compensated for this by discarding all sightings that we suspected may have been counted twice (as assessed from the direction of group flight from previous sighting). Overall, the limitations of our study may be balanced between overestimation and underestimation of the density. Although alternative survey designs have been suggested to overcome the difficulties involved in surveying primates (Buckland et al., 2010), they remain a challenge to implement in practice and it is likely that most estimates of primate density involve violations of some of the assumptions. Estimated densities can still be indicative of relative abundance and can be compared between studies when survey biases are similar. Hence it is essential to assess potential violations of assumptions in all distance sampling studies. Distance sampling remains the best method available to estimate density of colobines.

\section{Conservation of $P$. nemaeus in Nakai-Nam Theun National Protected Area}

Our density estimate for $P$. nemaeus in Nakai-Nam Theun National Protected Area falls within the range of that of other colobines elsewhere in South-east Asia (Table 4). Detection frequencies from surveyed areas can also be indicative of the relative abundance of a species in an area, which is in general proportionally equivalent to group density estimates (Table 4 ).

The conservative estimate of suitable habitat for the species in Nakai-Nam Theun is c. $1,600 \mathrm{~km}^{2}$, which is probably larger than areas of suitable habitat where the species occurs in Vietnam and Cambodia. In Vietnam the largest remaining populations of $P$. nemaeus are relatively small (Table 4 ) as a result of continuous deforestation and high hunting pressure (Lippold \& Vu, 2008; Blair et al., 2011; Coudrat et al., 2012). The species is already locally extinct in several areas in Vietnam. The population in the central region of the limestone-dominated Phong Nha-Ke Bang National Park may remain naturally protected because poor accessibility prevents overhunting. However, the population of Son Tra National Reserve is located in an increasingly human-dominated landscape and the species will only be maintained there by ongoing species-focused conservation projects (Lippold \& Vu, 2008; Dinh Thi Phuong Anh et al., 2010; Ulibarri \& Streicher, 2012). If no action is taken the same situation is likely to occur in Lao PDR, at least in the most accessible areas, as the value of the species in international trade increases as it becomes increasingly rare and the human population grows, putting more pressure on the species and its natural habitat.

In Seima Biodiversity Conservation Area, in eastern Cambodia, a population of the closely related black-shanked douc Pygathrix nigripes has an estimated density of c. 7 groups per km² (Pollard et al., 2007; O’Kelly \& Nut, 2010). This population is the largest in the world for this species and is considered to be secure as a result of long-term conservation efforts in the area and low hunting pressure (WCS, 2009; O'Kelly \& Nut, 2010). The discovery of this large population was covered in the media, which helped promote the importance of the area for wildlife conservation. In 2009 a core area within the Conservation Area was designated as the Seima Conservation Forest by the Cambodian government, and a relatively successful conservation project was implemented (Evans et al., 2012). This example demonstrates the importance of communicating, both nationally and internationally, the findings from such studies. A similar case could be made for Nakai-Nam Theun National Protected Area.

The population of $P$. nemaeus in Lao PDR is the world's largest and offers the best hope for the species' conservation (Coudrat et al., 2012). However, it is far from secure because of the lack of or failure of management strategies. Wildlife in Nakai-Nam Theun National Protected Area has been under increasing hunting pressure from local and Vietnamese hunters, both for local consumption and the lucrative international trade (Nooren \& Claridge, 2001; Robichaud et al., 2009). As a result of the demand from Vietnam and China for colobine bones for use in traditional medicine (Nooren \& Claridge, 2001), douc populations are decreasing in Vietnam and the threat to Lao PDR populations (especially near the border with Vietnam) is likely to increase. Doucs are often traded in Lao PDR (Davidson et al., 1997; Nooren \& Claridge (2001); Phiapalath, 2009; Coudrat et al., 2012).

The Asian Species Action Partnership established to tackle the ongoing South-east Asian species extinction crisis highlights the importance of effective site-based speciesfocused projects (Duckworth et al., 2012). There is currently no species-specific conservation of $P$. nemaeus in Lao PDR but a long-term conservation project is planned for NakaiNam Theun National Protected Area (Coudrat, 2012). 
TABLE 4 Comparison of estimates of colobine density in South-east Asia, with species, location, overall detection frequency, group density, and source. Note that methodologies differ between studies, which can lead to violation of some of the assumptions of the distance sampling method (refer to the specific studies for details of methodologies).

\begin{tabular}{|c|c|c|c|c|}
\hline Species & Location & $\begin{array}{l}\text { Overall detection } \\
\text { frequency } \\
\left(\text { no. of sightings km }{ }^{-1} \text { ) }\right.\end{array}$ & $\begin{array}{l}\text { Group density } \\
\text { (no. of groups } \mathrm{km}^{-2} \text { ) }\end{array}$ & Source \\
\hline Pygathrix nemaeus & Nakai-Nam Theun National Protected Area, Lao PDR & 0.20 & 2.8 & This study \\
\hline P. nemaeus & Him Namno National Protected Area, Lao PDR & 0.32 & Phiapalath (2009) & \\
\hline P. nemaeus & Phong Nha-Khe Bang National Park, Vietnam & 0.04 & 0.25 & Haus et al. (2009) \\
\hline P. nemaeus & Son Tra National Park, Vietnam & $0.31^{1}$ & $\begin{array}{l}\text { Lippold \& Vu (2008); } \\
\text { Dinh Thi Phuong Anh et al. (2010) }\end{array}$ & \\
\hline Pygathrix nigripes & Seima Conservation Forest, Cambodia & 0.51 & $7.06^{2}$ & $\begin{array}{l}\text { Pollard et al. (2007); } \\
\text { O'Kelly \& Nut (2010) }\end{array}$ \\
\hline Trachypithecus phayrei & Phu Khieo Wildlife Sanctuary, Thailand & 0.26 & $3.4^{3}$ & Borries et al. (2002) \\
\hline T. phayrei & Phu Khieo Wildlife Sanctuary, Thailand & 0.26 & 3.4 & Hassel-Finnegan et al. (2008) \\
\hline Trachypithecus hatinhensis & Phong Nha-Khe Bang National Park, Vietnam & 0.08 & 0.5 & Haus et al. (2009) \\
\hline Presbytis potenziani & South Peleonan, Siberut, Indonesia & 0.64 & 3.2 & Waltert et al. (2008) \\
\hline P. potenziani & North Peleonan, Siberut, Indonesia & 0.33 & 1.8 & Quinten et al. (2009) \\
\hline Presbytis hosei & Kalimantan, Borneo, Indonesia & $2.3^{4}$ & Nijman (2004) & \\
\hline Simias concolor & North Peleonan, Siberut, Indonesia & 1.59 & 21.1 & Quinten et al. (2009) \\
\hline
\end{tabular}

${ }^{1}$ Inferred from 13 groups encountered over a total forested area of $41.9 \mathrm{~km}^{2}$

${ }^{2}$ Mean group density for annual estimates from 2005 to 2010

${ }^{3}$ Calculated with strip transect method (NRC, 1981)

${ }^{4}$ Result for primary hill forest survey, estimated using effective distance method (Whitesides et al., 1988) 
This will be the country's first such research project for this little-known species and will apply best practices to secure its conservation (Sunderland et al., 2012). The project has the potential to ensure the survival of the red-shanked douc in Lao PDR as well as other threatened and unique species of the Annamite mountain range.

\section{Acknowledgements}

Permission to undertake the field survey in Nakai-Nam Theun National Protected Area was granted by the Department of Forestry of the Ministry of Agriculture and Forestry of Lao PDR. The NT2-WMPA provided support throughout CNZC's PhD research in Nakai-Nam Theun; we thank Phouthone Sophathilath, Thong-Eth Phayvanh and Soukhatha Vannalath. We thank the local people who assisted during data collection; Will Duckworth, Bill Robichaud, Latsamay Sylavong and Phaivanh Phiapalath, who provided advice and support; and Prof. Bounthob and Onvilay Souliya of The National University of Laos, who provided logistical support. CNZC's $\mathrm{PhD}$ research was funded by the Mohamed Bin Zayed Species Conservation Fund, International Primatological Society, American Society of Primatologists, Primate Society of Great Britain, Primate Action Fund (through Conservation International), Primate Conservation Inc., and Idea Wild. We thank the reviewers for their comments.

\section{References}

Blair, M.E., Sterling, E.J. \& Hurley, M.M. (2011) Taxonomy and conservation of Vietnam's primates: a review. American Journal of Primatology, 73, 1093-1106.

Borries, C., Larney, K., Kreetiyutanont, K. \& Koenig, A. (2002) The diurnal primate community in a dry evergreen forest in $\mathrm{Phu}$ Khieo Wildlife Sanctuary, northeast Thailand. Natural History Bulletin of the Siam Society, 50, 75-88.

Boyce, M.S., Vernier, P.R., Nielsen, S.E. \& Schmiegelow, F.K. (2002) Evaluating resource selection functions. Ecological Modelling, 157, 281-300.

Buckland, S.T., Anderson, D.R., Burnham, K.P., LaAke, J.L., Borchers, D.L. \& Thomas, L. (2001) Introduction to Distance Sampling-Estimating Abundance of Biological Populations. Oxford University Press, Oxford, UK.

Buckland, S.T., Plumptre, A.J., Thomas, L. \& Rexstad, E.A. (2010) Design and analysis of line transect surveys for primates. International Journal of Primatology, 31, 833-847.

Coudrat, C.N.Z. (2012) Conservation of the World's Most Beautiful Primate, the Red-shanked Douc (Pygathrix Nemaeus) in Lao PDR. EAZA Conservation Forum 2012 'Love and Loss', Vienna, Austria.

Coudrat, C.N.Z., Duckworth, J.W. \& Timmins, R.J. (2012) Distribution and conservation status of the red-shanked douc (Pygathrix nemaeus) in Lao PDR: an update. American Journal of Primatology, 74, 874-889.

Davidson, P., Robichaud, W.G., Tizard, R.J., Vongkhamheng, C. \& Wolstencroft, J. (1997) A Wildlife and Habitat Survey of Dong
Ampham NBCA, Attapu Province, Lao PDR. Wildlife Conservation Society, Vientiane, Lao PDR.

Dinh Thi Phuong Anh, Nguyen Dinh Hong Chung \& Huynh Thi Nguyet Hang (2010) Status and distribution of red-shanked douc langurs (Pygathrix nemaeus) and threats to their population at Son Tra Nature Reserve, Danang City. In Conservation of Primates in Indochina (eds T. Nadler, B. Rawson \& V.N. Thinh), pp. 71-78. Frankfurt Zoological Society, Endangered Primate Rescue Center, Cuc Phuong National Park and Conservation International, IndoBurma Program, Hanoi, Vietnam.

Dormann, C.F., Elith, J., Bacher, S., Buchmann, C., Carl, G., CARré, G. et al. (2012) Collinearity: a review of methods to deal with it and a simulation study evaluating their performance. Ecography, $35,1-20$.

Duckworth, J.W., Batters, G., Belant, J.L., Bennett, E.L., Brunner, J., Burton, J. et al. (2012) Why South-East Asia should be the world's priority for averting imminent species extinctions, and a call to join a developing cross-institutional programme to tackle this urgent issue. SAPIENS, 5, 76-95.

Evans, T.D., O’Kelly, H.J., Men, S., Nut, M.H., Pet, P., Pheakdey, S. \& Pollard, E.H.B. (2012) In Evidence-based Conservation: Lessons from the Lower Mekong (eds T.C.H. Sunderland, J. Sayer \& M.-H. Hoang), pp. 157-186. Routledge, Abingdon, UK.

Hassel-Finnegan, H.M., Borries, C., Larney, E., Umponjan, M. \& Koenig, A. (2008) How reliable are density estimates for diurnal primates? International Journal of Primatology, 29, 1175-1187.

Haus, T., Vogt, M., Forster, B., Vu, N.T. \& Ziegler, T. (2009) Distribution and population densities of diurnal primates in the Karst Forests of Phong Nha-Ke Bang National Park, Quang Binh Province, Central Vietnam. International Journal of Primatology, 3o, 301-312.

Hijmans, R.J., Cameron, S.E., Parra, J.L., Jones, P.G. \& Jarvis, A. (2005) Very high resolution interpolated climate surfaces for global land areas. International Journal of Climatology, 25, 1965-1978.

Hirzel, A.H., Le Lay, G., Helfer, V., Randin, C. \& Guisan, A. (2006) Evaluating the ability of habitat suitability models to predict species presences. Ecological Modelling, 199, 142-152.

HoANG, M.D. (2007) Ecology and conservation status of the blackshanked douc (Pygathrix nigripes) in Nui Chua and Phuoc Binh National Parks, Ninh Thuan Province, Vietnam. PhD thesis. University of Queensland, Brisbane, Australia.

IUCN (2012) IUCN Red List of Threatened Species. Http://www. iucnredlist.org [accessed January 2013].

KoH, L.P. \& SoDHI, N.S. (2010) Conserving Southeast Asia's imperiled biodiversity: scientific, management, and policy challenges. Biodiversity and Conservation, 19, 913-917.

Kohavi, R. (1995) A study of cross-validation and bootstrap for accuracy estimation and model selection. In Proceedings of the Fourteenth International Joint Conference on Artificial Intelligence, pp. 1137-1143. Morgan Kaufmann, San Francisco, USA.

Lip pold, L.K. \& VU, N.T. (2008) The time is now: survival of the douc langurs of Son Tra, Vietnam. Primate Conservation, 23, 75-79.

Marshall, A.R., Lovett, J.C. \& White, P.C.L. (2008) Selection of line-transect methods for estimating the density of group-living animals: lessons from the primates. American Journal of Primatology, 70, 452-462.

Merckx, B., Steyaert, M., Vanreusel, A., Vincx, M. \& VANAVERBEKe, J. (2011) Null models reveal preferential sampling, spatial autocorrelation and overfitting in habitat suitability modelling. Ecological Modelling, 222, 588-597.

Nadler, T. (2010) Status of Vietnamese primates-complements and revisions. In Conservation of Primates in Indochina (eds T. Nadler, B. Rawson \& V.N. Thinh), pp. 3-16. Frankfurt Zoological Society, 
Endangered Primate Rescue Center, Cuc Phuong National Park and Conservation International, Indo-Burma Program, Hanoi, Vietnam.

National Assembly Lao PDR (2007a) Forestry Law. Government of the Lao People's Democratic Republic, Vientiane, Lao PDR.

National Assembly Lao PDR (2007b) Wildlife and Aquatic Law. Government of the Lao People's Democratic Republic, Vientiane, Lao PDR.

Nijman, V. (2004) Effects of habitat disturbance and hunting on the density and the biomass of the endemic Hose's leaf monkey Presbytis hosei (Thomas, 1889) (Mammalia: Primates: Cercopithecidae) in east Borneo. Contributions to Zoology, 73, 1-10.

Nooren, H. \& Claridge, G. (2001) Wildlife Trade in Laos: The End of the Game. The Netherlands Committee for the IUCN, Amsterdam, The Netherlands.

NRC (National Research Council) (1981) Techniques for the Study of Primate Population Ecology. National Academy Press, Washington, DC, USA.

Ogutu, J.O., Bhola, N., Piepho, H.-P. \& Reid, R. (2006) Efficiency of strip- and line-transect surveys of African savanna mammals. Journal of Zoology, 269, 149-160.

O’Kelly, H. \& Nut, M.H. (2010) Monitoring of Key Wildlife Populations in Seima Protection Forest, Cambodia 2005-2010. Wildlife Conservation Society, Phnom Penh, Cambodia.

Phiapalath, P. (2009) Distribution, behaviour and theat of redshanked douc langur Pygathrix nemaeus in Hin Namno National Protected Area, Khammouane Province, Lao PDR. PhD thesis. Suranaree University of Technology, Nakhon Ratchasima, Thailand.

Phillips, S.J., Anderson, R.P. \& Schapire, R.E. (2006) Maximum entropy modeling of species geographic distributions. Ecological Modelling, 190, 231-259.

Phillips, S.J. \& Dudik, M. (2008) Modeling of species distributions with Maxent: new extensions and a comprehensive evaluation. Ecography, 31, 161-175.

Phillips, S.J., Dudík, M. \& Schapire, R.E. (2004) A maximum entropy approach to species distribution modeling. Proceedings of the 21st International Conference on Machine Learning, pp. 83-90, Banff, Canada.

Phillips, S.J., Dudík, M., Elith, J., Graham, C.H., Lehmann, A., Leathwick, J. \& Ferrier, S. (2009) Sample selection bias and presence-only distribution models: implications for background and pseudo-absence data. Ecological Applications, 19, 181-97.

Plumptre, A.J. \& Cox, D. (2006) Counting primates for conservation: primate surveys in Uganda. Primates, 47, 65-73.

Pollard, E., Clements, T., Nut, M.H., Ko, S. \& Rawson, B. (2007) Status and Conservation of Globally Threatened Primates in the Seima Biodiversity Conservation Area. Wildlife Conservation Society, Phnom Penh, Cambodia.

Quinten, M.C., Waltert, M., Syamsuri, F. \& Hodges, J.K. (2009) Peat swamp forest supports high primate densities on Siberut Island, Sumatra, Indonesia. Oryx, 44, 147.

Rawson, B. \& Roos, C. (2008) A new primate species record for Cambodia: Pygathrix nemaeus. Cambodian Journal of Natural History, 2008, 7-11.

Rawson, B.M. (2009) The socio-ecology of the black-shanked douc in Mondulkiri Province, Cambodia. PhD thesis. Australian National University, Canberra, Australia.

Robichaud, B., Marxh, C., Southammakoth, S. \& Khounthikoummane, S. (2001) Review of the National Protected Area System of Lao PDR. Lao-Swedish Forestry Programme, Department of Forestry and IUCN, Vientiane, Lao PDR.

Robichaud, W., Sinclair, A., Odarkor-Lanquaye, N. \& KlinkenberG, B. (2009) Stable forest cover under increasing populations of swidden cultivators in central Laos: the roles of intrinsic culture and extrinsic wildlife trade. Ecology and Society, 14,33 .

Sodhi, N.S., Koh, L.P., Brook, B.W. \& NG, P.K.L. (2004) Southeast Asian biodiversity: an impending disaster. Trends in Ecology \& Evolution, 19, 654-660.

Sodhi, N.S., Posa, M.R.C., Lee, T.M., Bickford, D., Koh, L.P. \& Brooк, B.W. (2009) The state and conservation of Southeast Asian biodiversity. Biodiversity and Conservation, 19, 317-328.

Sunderland, T.C.H., Sayer, J., Hoang, M.-H. (eds) (2012) Evidencebased Conservation: Lessons from the Lower Mekong. Routledge, Abingdon, UK.

Thomas, L., Buckland, S.T., Rexstad, E.A., Laake, J.L., StrindierG, S., Hedley, S.L. et al. (2010) Distance software: design and analysis of distance sampling surveys for estimating population size. Journal of Applied Ecology, 47, 5-14.

Timmins, R.J. \& Duckworth, J.W. (1999) Status and Conservation of Douc Langurs (Pygathrix nemaeus) in Laos. International Journal of Primatology, 20, 469-489.

Timmins, R.J. \& Evans, T.D. (1996) Wildlife and Habitat Survey of the Nakai-Nam Theun National Biodiversity Conservation Area. Wildlife Conservation Society, Vientiane, Lao PDR.

Tordoff, A.W., Baltzer, M.C., Fellowes, J.R., Pilgrim, J.D. \& LANGHAMmer, P.F. (2012) Key biodiversity areas in the Indo-Burma hotspot: process, progress and future directions. Journal of Threatened Taxa, 4, 2779-2787.

Ulibarri, L. \& Streicher, U. (2012) The "Son Tra Douc Langur Research and Conservation Project" of Frankfurt Zoological Society. Vietnamese Journal of Primatology, 2, 37-46.

VELOZ, S.D. (2009) Spatially autocorrelated sampling falsely inflates measures of accuracy for presence-only niche models. Journal of Biogeography, 36, 2290-2299.

Waltert, M., Abegg, C., Ziegler, T., Hadi, S., Priata, D. \& Hodges, K. (2008) Abundance and community structure of Mentawai primates in the Peleonan forest, north Siberut, Indonesia. Oryx, 42, 375-379.

WCS (2009) Best of the Wild: Wildlife Conservation Society and the Seima Protection Forest. Wildlife Conservation Society, Phnom Penh, Cambodia.

Whitesides, G.H., Oates, J.F., Green, S.M. \& Kluberdanz, R.P. (1988) Estimating primate densities from transects in a West African rain forest: a comparison of techniques. Journal of Animal Ecology, $57,345-367$.

\section{Biographical sketches}

Camille N. Z. Coudrat has conducted field work in Cambodia and Lao PDR since 2009. Her main research focus is the conservation and ecology of primates and other wildlife, and conservation education. She is continuing her research in Lao PDR, focusing on the conservation and behavioural ecology of the red-shanked douc and the white-cheeked gibbon in Nakai-Nam Theun National Protected Area. Chanthalaphone Nanthavong was responsible for wildlife monitoring and patrolling at the Nam Theun 2 Watershed Management and Protection Authority during 2006-2012. His research is currently focused on the ecology of the southern whitecheeked gibbon Nomascus siki in Nakai-Nam Theun National Protected Area. K. Anna I. Nekaris has studied Asian mammals in the wild and in captivity for more than 15 years. She has conducted field studies of all currently recognized taxa of slow and slender lorises and has initiated conservation awareness and capacity-building projects in numerous loris range countries. She is the director of the Little Fireface Project and the Nocturnal Primate Research Group. 